\title{
Teachers' Professional Reading Program in Higher Education: An Evaluation
}

\author{
Emmanuel James Pattaguan", Rachel Ann Surla², Darin Jan C. Tindowen ${ }^{3, *}$ \\ ${ }^{1}$ Vice President for Academics, University of Saint Louis, Tuguegarao City, Philippines \\ ${ }^{2}$ Faculty, School of Education, Arts and Sciences, University of Saint Louis, Tuguegarao City, Philippines \\ ${ }^{3}$ Head, Center for Social Innovation, Local Knowledge and Educational Research, University of Saint Louis, Tuguegarao City, \\ Philippines
}

Received August 5, 2019; Revised September 4, 2019; Accepted September 16, 2019

Copyright $(2019$ by authors, all rights reserved. Authors agree that this article remains permanently open access under the terms of the Creative Commons Attribution License 4.0 International License

\begin{abstract}
This study was conducted to describe the professional readings of teachers of the School of Education, Arts and Sciences and to evaluate the effectiveness of the Project READS Program of the university. The respondents of the study were the 31 full-time and part-time faculty members of the School of Education, Arts and Sciences of the School Year 2018-2019. The results revealed that Teacher Education and Liberal Arts educators are engaged in professional readings focusing on instructional strategies and assessment techniques. Furthermore, the Project READS program of the university is effective and sustainable as it attains its goal in enhancing the teaching process among Liberal Arts and Teacher Education faculty members.
\end{abstract}

Keywords Project READS, Teacher Education, Liberal Arts, Reading Program, Effectiveness

\section{Introduction}

The teaching profession is considered as a dynamic one. This can be attributed to the fact that the profession changes over time due to technological, societal, and economic developments. With the drastic changes that are happening, it is then important that teachers should have well-defined mechanisms to ensure that they stay informed about new ideas and developments that will be vital in their teaching practice and pedagogies (Desimone, 2009). Furthermore, it is also their responsibility to acquire and gain new innovations, ideas, practices, and even instructional materials and assessment techniques to improve the teaching practice. With these, teachers need to engage themselves with professional development activities.

Professional development is a growing concern of teachers across the world especially in the advent of the 21 st century education (Borko, 2004; Dede, Jass Ketelhut, Whitehouse, Breit, \& McCloskey, 2009). In education, the term professional development may be used in reference to a wide variety of specialized training, formal education, or advanced professional learning intended to help administrators, teachers, and other educators improve their professional knowledge, competence, skill, and effectiveness (Sparks, 2002; Ross \& Bruce, 2007). Teachers experience a wide variety of activities and programs that can increase their knowledge and skills, improve their teaching practice, and contribute to their personal, social, and emotional growth. Of all the vast range of professional development activities that teacher may engage to, professional readings are probably the most accessible and most convenient professional activity (Taylor, Pearson, Peterson, \& Rodriguez, 2005; Podhasjski, Mather, Nathan, \& Sammons, 2009).

Professional reading is one alternative for professional development that encourages teachers to investigate issues and problems and to search for solutions that will enhance their knowledge and skill in classroom practices (Cantrell \& Hughes, 2008). Despite the benefits that can be drawn from engaging into professional readings, still literatures reveal that teachers across levels do not really engage themselves regularly in professional readings and just rely on prescribed textbooks that will be used in their classroom discussion (Coburn, 2001; Powell, 2006; Hinrichs \& Ruhl-Smith, 1998). Furthermore, previous studies also revealed low utilization of teachers on the use of library materials especially on the use of journals, periodicals, and reference books (Rambo, 2012; Foster \& Inglis, 2018). These scenarios may lead to the issues and concerns in the classroom such as substantiality of the subject matter being discussed, teachers' professional development and growth, and negative effects and influence on teachers' work 
(Rambo, 2012; Powell, 2006).

With this kind of educational issue that is emerging in the 21 st century landscape, it is then important that schools and Higher Education Institutions to come up with initiatives and programs that will motivate teachers in engaging into professional readings. The University of Saint Louis, a CICM Catholic Higher Education Institution in Northern Luzon, has institutionalized a program dubbed as Project READS: Read Everything About your Field, Digest and Share. It's a program meant to increase the utilization of available library resources and also to enhance their teaching of the professional courses/subjects that they are assigned.

This study was conducted to describe the professional readings of Teacher Education and Liberal Arts faculty members and to evaluate the effectiveness of the Project READS Program of the university.

\section{The Project READS Program of the University of Saint Louis}

Rationale:

The School year 2012-2013 saw the birth of USL's new strategic direction with the crafting of the University's Institutional Development Plan or Strategic Plan for 2012-2017.Culled from the University's Strategic Plan is the first Key Result Area (KRA): Program Excellence and Relevance. Under this KRA is the goal of making the University Library as a prime resource and information venue in the Philippines. Specifically, it is the objective of USL to promote the library as a prime source of information to advance the teaching and learning process. In view of the fact that teachers play a vital role in the dispense of knowledge or information, coupled with the fact that USL continuously upgrade its library collection, library resources have been regularly updated. The utilization of these resources must be made to the maximum, hence the birth of PROJECT READS. The acronym READS taken on face value means that the good faculty member must be a reader himself/herself. Beyond the latter, READS stands for Read Everything About your field, Digest and Share.

From the foregoing, PROJECT READS is a program aimed at maximum utilization of available Journals, in print and on-line by the teachers so that they can use these readings to enhance their teaching of the professional subjects that they are assigned. This, notwithstanding of the fact that in the measure of his/her efficiency, a teacher must be able to relate his/her subject matter to other fields.

Project Objectives:

1. To intensify maximization of print and on-line resources available in the University Library for enhancement of teachers' teaching, and hence, students' learning

2. To develop the spirit of collaboration and dialogue among faculty members of every department
Project Champions:

- Vice-President for Academics

- Academic Deans

- High School Principal

- Elementary Principal

- Department Heads

- Area Coordinators

Project Mechanics:

1. Every Department Head/Area Coordinator shall schedule one or two faculty members every month to share a professional article from print and on-line journals to the Faculty in the department or area during faculty meetings

2. Minutes of Meeting, including the article shared will be provided to the Office of the Vice-President for Academics after the sharing. Reports will be provided every time a faculty shared for monitoring

3. At the end of the school year, Statistics on this Project shall be provided to Management for administrative use.

4. Evaluation shall be conducted periodically.

Project Presentation Specific Guideline for Teachers:

1. Select an article from print or on-line journals about the teacher's field or specialization

2. Propose this article for presentation to the Department Head or Area Coordinator for approval

3. Once approved, share this in the faculty meeting to be called for by the Coordinator/Head or Principal/Deans

4. The first part is reading of the article and the next part is sharing insights about the article.

\section{Methods}

This study utilized both quantitative and qualitative types of research to assess the implementation of the Project READS among Teacher Education and Liberal Arts faculty of University of Saint Louis, a Higher Education institution in Northern Philippines. The respondents of the study were the 31 faculty members of the School of Education, Arts and Sciences of the School Year 2018-2019. Table 1 shows the profile of the respondents. It can be seen in the table that there are more female teachers than male teachers in the study. Also, majority of the respondents are 21-40 years old coming from both Teacher Education and Liberal Arts areas. Furthermore, many of the respondents are master's degree holders. Finally, many of the teachers are teaching Teacher Education and Religious Education.

Both quantitative and open-ended questionnaires were used to assess the implementation of Project READS program of the university. The questionnaire is composed of three parts covering the following: (1) Professional 
Readings of the Faculty Members; (2) Evaluation of the Project READS program along aims, program effectiveness, program implementation, and program sustainability and (3) Effects of the Project READS Program to the personal and professional development of teachers.

In keeping with the ethics of the conduct of this research, the identity of the participants in this study was held in anonymity. Consent was sought for the conduct of the study from the participants as expressed by them.

Finally, descriptive statistics such as frequency and percentage were used to assess the Project READS program of the University. Furthermore, thematic analysis was used to explore the different effects of the Project READS program to the teaching and learning process as assessed by teachers.

Table 1. Profile of the Teacher Education and Liberal Arts Faculty Members

\begin{tabular}{|c|c|c|}
\hline Profile Variables & $\begin{array}{l}\text { Frequency } \\
(\mathrm{N}=31)\end{array}$ & Percentage \\
\hline \multicolumn{3}{|l|}{ Gender } \\
\hline Male & 15 & 48.39 \\
\hline Female & 16 & 51.61 \\
\hline \multicolumn{3}{|l|}{ Age } \\
\hline 21-30 years old & 12 & 38.71 \\
\hline $31-40$ years old & 10 & 32.26 \\
\hline $41-50$ years old & 6 & 19.35 \\
\hline 51 years old and above & 3 & 9.68 \\
\hline \multicolumn{3}{|l|}{ Department/Area } \\
\hline Teacher Education & 16 & 51.61 \\
\hline Liberal Arts & 15 & 48.39 \\
\hline \multicolumn{3}{|l|}{$\begin{array}{c}\text { Highest Educational } \\
\text { Attainment }\end{array}$} \\
\hline Bachelor's Degree Holder & 11 & 35.48 \\
\hline Law Graduate & 2 & 6.45 \\
\hline Master's Degree Holder & 13 & 41.94 \\
\hline Doctorate Degree Holder & 5 & 16.13 \\
\hline \multicolumn{3}{|l|}{ Field of Specialization } \\
\hline Teacher Education & 8 & 25.81 \\
\hline Languages & 6 & 19.35 \\
\hline $\begin{array}{c}\text { Political Science and Legal } \\
\text { Management }\end{array}$ & 5 & 16.13 \\
\hline Psychology & 4 & 12.90 \\
\hline Religious Education & 8 & 25.81 \\
\hline
\end{tabular}

\section{Results ad Discussion}

Table 2 presents the professional readings of Teacher Education and Liberal Arts faculty members. It can be seen from the table that majority of Teacher Education and Liberal Arts faculty members are engaged in reading articles and papers related to instructional strategies and assessment. This includes readings on $21^{\text {st }}$ century teaching strategies, assessment techniques, strategies that are geared towards better students' academic performance and studies towards teaching and learning. This means that Teacher Education and Liberal Arts faculty members are utilizing materials that will improve their teaching profession through reading appropriate and effective teaching strategies and even assessment techniques. This coincides with the notion that teachers especially those teaching general education and professional education courses are the ones who really developed and implemented effective strategies and assessment since they are the ones considered to be expert in this field (Aljughaiman \& Mowrer-Reynolds, 2005; Sanders, 2016).

Table 2. Professional Readings of Teacher Education and Liberal Arts Faculty Members

\begin{tabular}{|c|c|c|c|}
\hline Reading Subject & Frequency & Percentage & Rank \\
\hline $\begin{array}{c}\text { Instructional Strategies and } \\
\text { Assessment }\end{array}$ & 16 & 40.00 & 1 \\
\hline $\begin{array}{c}\text { Community Engagement and } \\
\text { Service Learning }\end{array}$ & 2 & 5.00 & 7 \\
\hline Classroom Management & 5 & 12.50 & 3 \\
\hline $\begin{array}{c}\text { Inspirational/ Motivational } \\
\text { Readings }\end{array}$ & 3 & 7.50 & 6 \\
\hline $\begin{array}{c}\text { Workplace Management and } \\
\text { Human Relations }\end{array}$ & 6 & 15.00 & 2 \\
\hline Social Sciences & 4 & 10.00 & 4.5 \\
\hline Teaching Profession & 4 & 10.00 & 4.5 \\
\hline
\end{tabular}

Meanwhile, other topics being read by Teacher Education and Liberal Arts faculty members are articles concerning workplace management and human relations, classroom management, the teaching profession, social sciences, inspirational and motivational readings, and community engagement and service learning. It is important to note that some Teacher Education and Liberal Arts faculty members are also engaged in reading articles related to workplace management and human relations. This may mean a holistic characteristic of Teacher Education and Liberal Arts faculty members in which they do not only consider their function as instructors but also emphasize their value as part of the larger organization. They are interested with topics pertaining to their workplace, which include stress management, relationships with supervisors and colleagues, human resource management, and conflict management. Furthermore, Teacher Education and Liberal Arts faculty members are also engaged in reading articles and papers that focus on classroom management. This may imply that teachers take into consideration on new approaches and techniques in managing classrooms and in promoting students' discipline in the classroom.

In summary, Teacher Education and Liberal Arts faculty members prefer to read pragmatic or application-oriented journals and periodicals that provided practical, hands-on materials or activities that could be immediately implemented in the classroom over theoretical ones. The findings are consistent with results of previous studies claiming that teachers' professional readings are more on practical and action-based topics which will lead to better student achievement and teachers' well-being (Applegate \& Applegate, 2004; Guthrie, 2004; Guthrie, Wigfield, \& You, 2012). 
Table 3. Evaluation of the Project READS Program

\begin{tabular}{|c|c|c|c|c|}
\hline \multirow{2}{*}{ Program Evaluation Elements } & \multicolumn{2}{|c|}{ Effective } & \multicolumn{2}{|c|}{ Not Effective } \\
\hline & Frequency & $\%$ & Frequency & $\%$ \\
\hline \multicolumn{5}{|l|}{ Project READS’ Aim } \\
\hline $\begin{array}{l}\text { PROJECT READS is a program aimed at maximum utilization of available Journals, in } \\
\text { print and on-line by the faculty/teachers so that they can use these readings to enhance } \\
\text { their teaching of the professional courses/subjects that they are assigned. }\end{array}$ & 33 & 97.06 & 1 & 2.94 \\
\hline \multicolumn{5}{|l|}{ Program Effectiveness } \\
\hline It translates to the teacher being able to relate his subject matter to the readings. & 32 & 94.12 & 2 & 5.88 \\
\hline It enhances students' learning and appreciation of the lessons. & 28 & 82.35 & 4 & 17.65 \\
\hline $\begin{array}{l}\text { It enhances faculty's reading habits so as to incorporate research findings and recent } \\
\text { developments in the field in the over-all discussion in class. }\end{array}$ & 32 & 94.12 & 2 & 5.88 \\
\hline \multicolumn{5}{|l|}{ Program Implementation } \\
\hline $\begin{array}{l}\text { The Program Chair/Area Coordinator/Department Head informed the faculty of the } \\
\text { Project READS implementation. }\end{array}$ & 31 & 91.18 & 3 & 8.82 \\
\hline The faculty member was given a schedule to share his/her readings during an area meeting. & 30 & 88.24 & 4 & 11.76 \\
\hline The faculty member volunteered to share during the meeting. & 30 & 88.24 & 4 & 11.76 \\
\hline $\begin{array}{l}\text { A follow-up by the program Chair/Area Coordinator/Department Head was made on those } \\
\text { who were not given opportunity to share. }\end{array}$ & 29 & 85.29 & 5 & 14.71 \\
\hline \multicolumn{5}{|l|}{ Program Sustainability } \\
\hline The program is sustainable and hence should be further implemented. & 34 & 100.00 & 0 & 0.00 \\
\hline
\end{tabular}

Table 3 presents the program evaluation of the Project READS as assessed by Teacher Education and Liberal Arts faculty members. In terms of the Project READS' main objective, it was revealed that the program is effective since Teacher Education and Liberal Arts faculty members believed that the program helps to enhance their teaching and pedagogy. This confirms the findings of previous studies that indeed, professional readings among faculty members are geared towards improvement and enhancement of the teaching practice (Timperley, Wilson, Barrar, \& Fung, 2008; Poskitt, 2005). Furthermore, teachers also believed that the main objective of the program is met which is on the maximum utilization of print and non-print journals in the university library. This means that through the program, journal being acquired by the university library, is being utilized by faculty members.

Meanwhile, the table also shows that as for its program effectiveness, Teacher Education and Liberal Arts faculty members assessed the Project READS program as effective. Specifically, they are able to relate the readings to their subject matters. This means that they are using the program as one of their strategies in their teaching practice. Through the program, teachers are able to use the readings as supplement to their discussion. This makes them become experts in their fields. The findings conform to the results of previous studies that the need for professional readings for teachers is to enhance their teaching methodologies especially on the delivery of the subject matter (Doubek \& Cooper, 2007; Opfer \& Peddler, 2011; Hasbrouck \& Tindal, 2006). Professional reading allows educators to explore new ideas, investigate issues, search for solutions to problems they face in the classroom, and enhance their knowledge and skill base in the classroom
(Rock \& Levine, 2002). Meanwhile, they also believe that the program enhances students' learning and appreciation of the lessons. This means that with the program, students are provided with wide and varied readings and instructional materials and are not only limited to the prescribed textbooks and references of the course. Studies revealed that the knowledge and skills base of educators is closely linked with student achievement in which engagement of teachers to professional readings leads to higher student achievement and increases students' interests in learning specific subjects and courses (Day, 2002; Piasta, Connor, Fishman, \& Morrison, 2009; Blair, Rupley, \& Nichols, 2007). Finally, Teacher Education and Liberal Arts faculty members also believe that the program enhances faculty's reading habits so as to incorporate research findings and recent developments in the field in the over-all discussion in class. The findings suggest that the program leads to the development and enhancement of research skills and capabilities among teachers since many studies argued that professional reading habits serve as one way in inculcating the culture of research among faculty members (Macalister, 2010; McNiff, 2010; Vescio, Ross, \& Adams, 2008).

Along program implementation, Teacher Education and Liberal Arts faculty members assessed the Project READS as effective. All faculty members are given opportunity to share their professional readings to their colleagues. Since teachers are engaged in this program, they are given opportunity to share their reflections and insights to other colleagues in a formal setting such as Departmental and area meetings. In this way, other teachers may also learn best practices and even strategies from different readings which they can also use in their own classes for them to 
really grow professionally and personally. Finally, all Teacher Education and Liberal Arts faculty members agreed that since the program is effective, it should be further implemented and be sustained.

\section{Effects of the Project READS Program to the Personal and Professional Development of Teachers}

As to the effects of the implementation of Project READS program to the personal and professional development of teacher education and liberal arts teachers, three major themes emerged based on the responses of the respondents. These themes include (1) improvement of the teaching practice, (2) enhancement of skills in doing and writing research papers, (3) promotion of the skill of collaboration among faculty members, and (4) active engagement into professional reading.

\section{a. Improvement of Teaching Practice}

The primary effect of the implementation of Project READS in higher education as revealed in the present study is the improvement of teaching practice. This means that teacher education and liberal arts faculty members believed that the program helped them deliver the instruction to students more effectively since they have additional resource materials that they may need in the class. Previous studies conducted revealed that professional reading programs implemented by different educational institutions primarily aimed to improve the teaching practice and as a result, will lead to better learning experience among learners (Applegate \& Applegate, 2004; Borko, 2004). Some of the verbalizations are as follows:

TE 03: What I like about the Project READS program is that I really become a master of my field whenever I am in the class. I can share many insights and information to my students and my discussion is not limited to the textbook and references required in the subject that I teach.

TE 20: Because of Project READS, I am now more engaged with my students because my teaching methodology has improved a lot because class discussion is now research-based and students are now exposed to varied reading materials that can supplement our discussion.

b. Enhancement of Skills in Doing and Writing Research Papers

One important and positive effect of the implementation of the Project READS program among teacher education and liberal arts teachers is the enhancement of their skills in doing and writing research papers. It has been stressed that research is one of the major functions of teachers in higher education. Studies conducted revealed that still, research has been the weakness of many teachers in higher education (Tindowen, Guzman, \& Macanang, 2019; Murawski, 2003). They still find difficulty in doing and writing research papers. In this present study, it is important to note that the Project READS program serves as an intervention to address the problem on research writing among faculty members. It was found out in the study that the program helps faculty members enhance their skills in doing research works. Some of the verbalizations are as follows:

TE14: Project READS helps me to really enhance my skills in doing research. I was able to synthesize literature and studies properly because of the program. My constant engagement in professional reading ignites my desire to really conduct and finish a research paper. TE25: Project READS is like doing the different processes of research. And with that, I am thankful. I am able to write and conduct simple research papers and I hope that I can really finish a full-blown research paper at the end of the semester.

c. Promotion of the Skill of Collaboration among Faculty Members

Collaboration is one of the important $21^{\text {st }}$ century skills that teachers should develop. Collaboration skills refer to individuals being able to work together to solve problems or answer questions, to work effectively and respectfully in teams, to accomplish a common goal and to assume shared responsibility for completing a task (Hixson, Ravitz, \& Whisman, 2012; Tindowen, Bassig, \& Cagurangan, 2017). Moreover, collaboration is one of the four skills that the University of Saint Louis is promoting to all of its stakeholders as a $21^{\text {st }}$ century education promoter (Pattaguan, 2016). The skill of collaboration was also developed among faculty members of Teacher Education and Liberal Arts as a result of the implementation of the Project READS program. Some of the verbalizations are as follows:

TE01: What I learned in the implementation of the Project READS program is the skill of collaboration.

Through the program, I am able to collaborate and link with other faculty members in the department. And with that, I already built harmonious relationship with my colleague.

TE05: Collaboration is being nurtured in the implementation of the program. We are able to link and build connections with other faculty members regardless of our area and department.

\section{d. Active Engagement into Professional Reading}

Finally, the last theme that emerged from the responses of the teachers on the effects of the Project READS is their active engagement into professional reading. Because of the program, faculty members began to love reading professional articles. Some of their verbalizations are as follows:

TE10: The program ignited in me the habit of reading. Instead of doing things that are not important, I just engaged myself with reading articles in published journals for my personal and professional growth.

TE03: I developed the habit of reading because of 
Project READS. I always make sure that I will be able to read at least one professional article every week.

\section{Conclusions}

The study concludes that teacher education and liberal arts faculty members are engaged in professional readings focusing on instructional strategies and assessment techniques. Furthermore, the Project READS program of the university is effective and sustainable as it attains its goal in enhancing the teaching process among the faculty of Liberal Arts and Teacher Education programs. Finally, the implementation of the Project READS program promotes positive effects among teachers personally and professionally.

\section{Recommendations}

The Office of the Vice President for Academics and Academic Deans should sustain the implementation of the said program.

Future researchers may dwell into the impact of the program on the teaching and learning process especially if it translates to better students' learning outcomes.

Academic Deans may also come up with a strategy to implement Project READS sharing in multidisciplinary and interdisciplinary approaches in which teachers may share professional readings to other departments.

\section{REFERENCES}

[1] Aljughaiman, A., \& MOWRER-REYNOLDS, E. L. I. Z. A. B. E. T. H. (2005). Teachers' conceptions of creativity and creative students. The Journal of Creative Behavior, 39(1), 17-34.

[2] Applegate, A. J., \& Applegate, M. D. (2004). The Peter effect: Reading habits and attitudes of preservice teachers. Reading Teacher, 57(6), 554-565.

[3] Borko, H. (2004). Professional development and teacher learning: Mapping the terrain. Educational researcher, 33(8), $3-15$.

[4] Blair, T. R., Rupley, W. H., \& Nichols, W. D. (2007). The effective teacher of reading: Considering the "what" and "how" of instruction. The Reading Teacher, 60(5), 432-438.

[5] Cantrell, S. C., \& Hughes, H. K. (2008). Teacher efficacy and content literacy implementation: An exploration of the effects of extended professional development with coaching. Journal of literacy research, 40(1), 95-127.

[6] Coburn, C. E. (2001). Collective sensemaking about reading: How teachers mediate reading policy in their professional communities. Educational evaluation and policy analysis, 23(2), 145-170.
[7] Day, R. (2002). Top ten principles for teaching extensive reading. Reading in a foreign language, 14(2), 136.

[8] Dede, C., Jass Ketelhut, D., Whitehouse, P., Breit, L., \& McCloskey, E. M. (2009). A research agenda for online teacher professional development. Journal of teacher education, 60(1), 8-19.

[9] Desimone, L. M. (2009). Improving impact studies of teachers' professional development: Toward better conceptualizations and measures. Educational researcher, 38(3), 181-199.

[10] Doubek, M. B., \& Cooper, E. J. (2007). Closing the gap through professional development: Implications for reading research. Reading Research Quarterly, 42(3), 411-415.

[11] Foster, C., \& Inglis, M. (2018). Mathematics Teacher Professional Journals: What Topics Appear and How Has This Changed over Time? International Journal of Science and Mathematics Education, 1-22.

[12] Guthrie, J. T. (2004). Teaching for literacy engagement. Journal of literacy research, 36(1), 1-30.

[13] Guthrie, J. T., Wigfield, A., \& You, W. (2012). Instructional contexts for engagement and achievement in reading. In Handbook of research on student engagement (pp. 601-634). Springer, Boston, MA.

[14] Hasbrouck, J., \& Tindal, G. A. (2006). Oral reading fluency norms: A valuable assessment tool for reading teachers. The Reading Teacher, 59(7), 636-644.

[15] Hinrichs, S., \& Ruhl-Smith, C. (1998). Keeping current: A research study of educators' reading habits. Journal of Texas State Reading Association, 5, 77-82.

[16] Hixson, N., Ravitz, J., \& Whisman, A. (2012). Extended professional development in project-based learning: Impacts on 21 st century teaching and student achievement. Charleston: West Virginia Department of Education.

[17] Macalister, J. (2010). Investigating teacher attitudes to extensive reading practices in higher education: Why isn't everyone doing it? Relc Journal, 41(1), 59-75.

[18] McNiff, J. (2010). Action research for professional development: Concise advice for new action researchers. Dorset: September books.

[19] Murawski, W. W. (2003). School collaboration research: Successes and difficulties. Academic Exchange Quarterly, 7(3), 104-109.

[20] Opfer, V. D., \& Pedder, D. (2011). Conceptualizing teacher professional learning. Review of educational research, 81(3), 376-407.

[21] Pattaguan, E. J. P. (2016). To Be on Top: A Sustained Outcomes-Based Accountancy Education Experience. Journal of Business Studies Quarterly, 7(3), 127.

[22] Piasta, S. B., Connor, C. M., Fishman, B. J., \& Morrison, F. J. (2009). Teachers' knowledge of literacy concepts, classroom practices, and student reading growth. Scientific Studies of Reading, 13(3), 224-248.

[23] Podhajski, B., Mather, N., Nathan, J., \& Sammons, J. (2009). Professional development in scientifically based reading instruction: Teacher knowledge and reading outcomes. 
Journal of Learning Disabilities, 42(5), 403-417.

[24] Poskitt, J. (2005). Towards a model of New Zealand school-based teacher professional development. New Zealand Journal of Teachers' Work, 2(2), 136-151.

[25] Powell, M. P. (2006). Teachers and professional reading: a study of reading experience and administrative support across traditional, Paideia, and PDS schools (Doctoral dissertation).

[26] Rambo, S. M. (2012). Professional reading and high quality professional development (Doctoral dissertation, Capella University)

[27] Ross, J., \& Bruce, C. (2007). Professional development effects on teacher efficacy: Results of randomized field trial. The journal of educational research, 101(1), 50-60.

[28] Sanders, S. (2016). Critical and creative thinkers in mathematics classrooms. Journal of Student Engagement: Education Matters, 6(1), 19-27.

[29] Sparks, D. (2002). Designing Powerful Professional Development for Teachers and Principals.

[30] Taylor, B. M., Pearson, P. D., Peterson, D. S., \& Rodriguez, M. C. (2005). The CIERA school change framework: An evidence-based approach to professional development and school reading improvement. Reading Research Quarterly, 40(1), 40-69.

[31] Timperley, H., Wilson, A., Barrar, H., \& Fung, I. (2008). Teacher professional learning and development.

[32] Tindowen, D. J. C., Bassig, J. M., \& Cagurangan, J. A. (2017). Twenty-First-Century skills of alternative learning system learners. SAGE Open, 7(3), 2158244017726116

[33] Tindowen, D. J., Guzman, J., \& Macanang, D. (2019). Teachers' conception and difficulties in doing action research. Universal Journal of Educational Research, 7(8), 1787-1794.

[34] Vescio, V., Ross, D., \& Adams, A. (2008). A review of research on the impact of professional learning communities on teaching practice and student learning. Teaching and teacher education, 24(1), 80-91. 